\title{
Of Making Many Copies There is No End: The Digitization of Manuscripts and Printed Books in Arabic Script ${ }^{1}$
}

The invisibility of the medium makes its use instrumental and decreases the fascination with technology. Marija Dalbello, "A Genealogy of Digital Humanities."

Ever since the fifteenth century those who have made facsimiles have been at pains to stress how close they are to their models. The claims of modern e-publishing are not new.

David McKitterick, Old Books, New Technologies

The digitization of manuscripts and printed books occurs in a wide range of socio-economic and political contexts. In the following I will use the distinction between "physical book" and "written text" to highlight the difference between the material artefact and its literary content. While a book's physicality is immediately experienced whenever we open a manuscript or printed book, the materiality of an e-book is primarily noticed whenever a reading device indicates that there is no storage space left for saving yet another digital file. The most common application of digitization remains the commercial and not-for-profit publication of written texts which were not "born-digital" as e-books. This application aims at facilitating access to literary content by creating a digital copy of a written text. ${ }^{2}$

Figure 1. The Book in the Islamic World, ed. George Atiyeh (Washington: Library of Congress, 1995), 33. Viewed on EBSCOhost (screenshot, 21 January 2015).

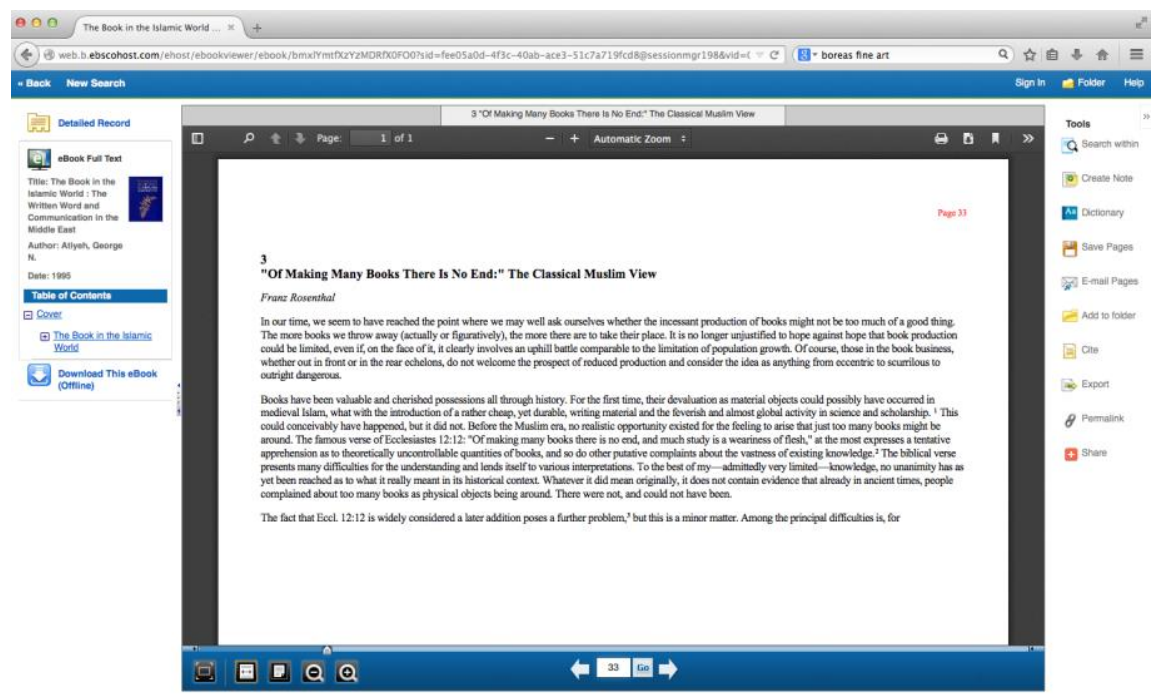

1 This essay is a revised version of the paper on "Manuscripts and Printed Books in Arabic Script in the Age of the e-Book: The Challenges of Digitization," presented on 23 October 2013 at the symposium on Digital Humanities and Islamic and Middle East Studies at Brown University. I am much indebted to Karin Hörner, Jane R. Siegel, and Elias Muhanna for their insightful comments on the essay's first version. All errors are mine.

2 With regard to the digitization of Arabic literature, the most recent project is NYU's Arabic CollectionsOnline, which offers a digital library of public domain Arabic language content at: http://dlib.nyu.edu/aco/. 
Figure 2. Naunidhi Ra'ē, Dastūr al-șibyān ([Lucknow]: Mațba'-i Hasanī 1261/1845), 3. Persian lithographed pamphlet, paper, no measurements provided. From the library of Sa'īd Nafisī (1895-1966). Rare Book and Manuscript Library of Columbia University, 892.84 N225. Viewed in the HathiTrust Digital Library (screenshot, 29 January 2015).

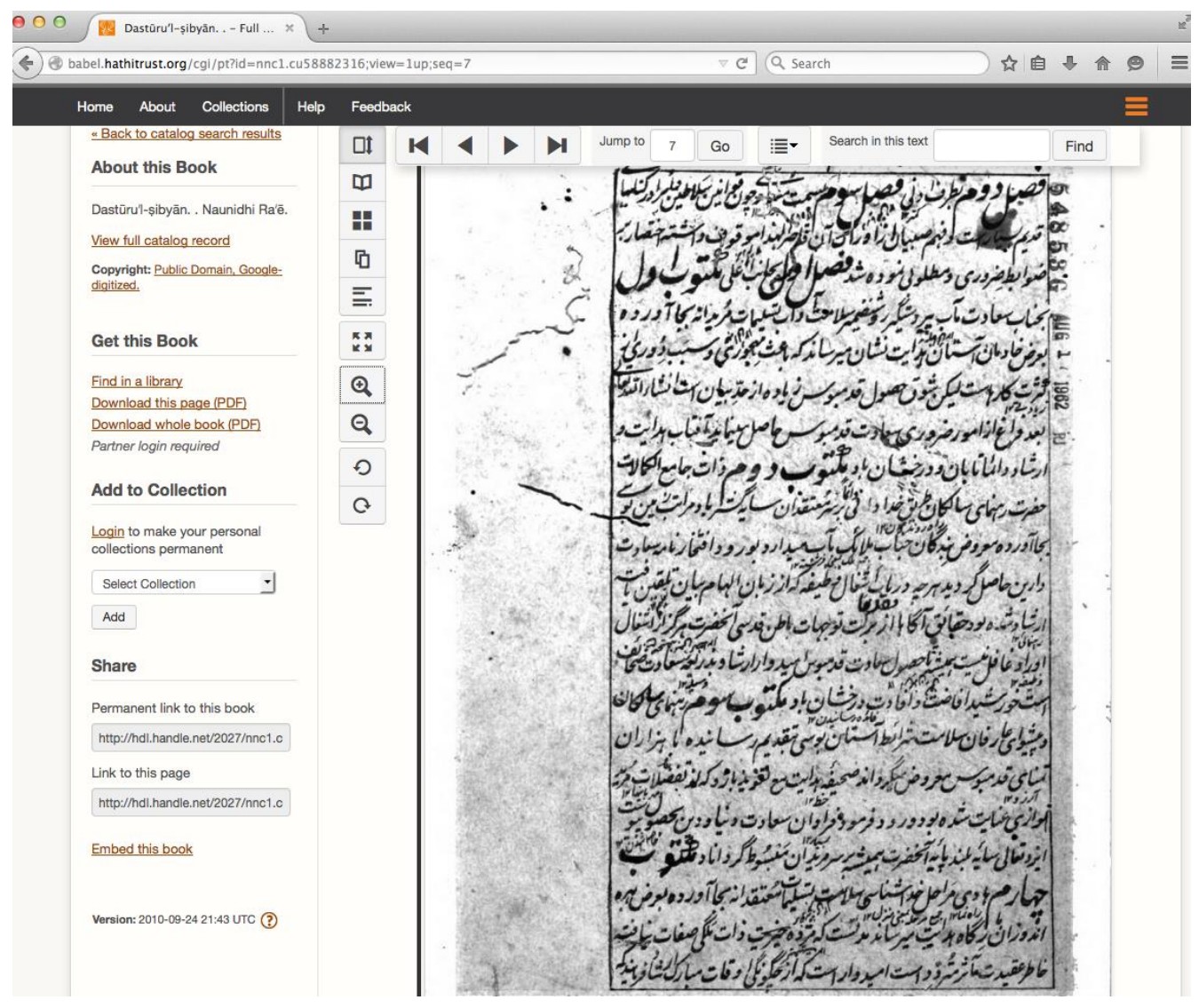

A decade after the announcement of "Google Print" at the Frankfurt Book Fair and the launch of the "Google Books Library Project" in the US, electronic texts are no longer experienced as novel or strange, ${ }^{3}$ even though many readers report that, if at all possible, they still prefer the tangibility of physical books for the reading of monographs. ${ }^{4}$ But manuscripts and printed books are also digitized in order to create digital surrogates of physical books as material artefacts.

\footnotetext{
3 Wendu Hui Kyong Chun and Lisa Marie Rhody, "Working the Digital Humanities: Uncovering Shadows between the Dark and the Light," differences: A Journal of Feminist Cultural Studies 25, no. 1 (2014): "unless there is a core contingent of faculty who continue to distribute their work in typed manuscripts and consult print indexes of periodicals that I don't know about, everyone is already a digital humanist" (9); cf. Hubertus Kohle, Digitale Bildwissenschaft (Glückstadt: Verlag Werner Hülsbusch, 2013), 9.

4 Roger C. Schonfield, "Stop the Presses: Is the Monograph Headed toward an E-only Future?" issue brief, Ithaka S+R, 10 December 2013, 5 n. 10;

http://sr.ithaka.org/sites/default/files/files/SR_BriefingPaper_Presses_120913.pdf
} 
Figure 3. Miscellany of 23 literary works, fols. 6a and 6b. MS pers., paper, $18.4 \times 12.7 \mathrm{~cm}$. Compiled for Sultān Jalāl al-Dīn Iskandar b. 'Umar Shaykh, a grandson of Timur and ruler of Fārs, between 813/1410 and 814/1411. British Library, Add MS 27261. Viewed in the British Library's collection of Digitised Manuscripts (screenshot, 21 January 2015).

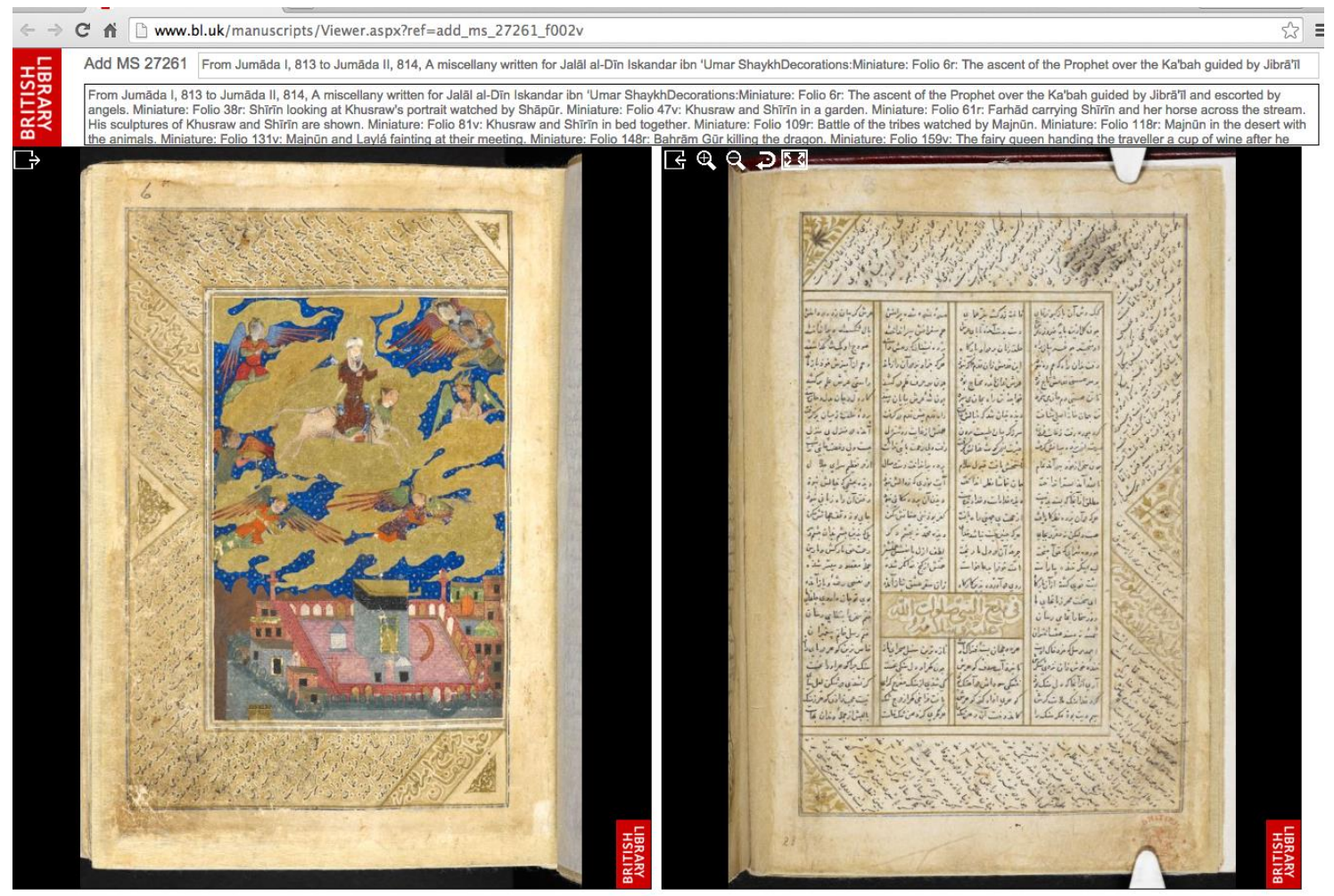

These digital surrogates preserve not only the originals' literary content, they also show, as far as possible in two-dimensional images, the originals' physical evidence and paratexts, both of which document the historical circumstances of the originals' manufacture, ownership, and use. ${ }^{5}$ The different applications of digitization cannot be strictly separated from each other. For example, digitally published critical editions and facsimiles are instances of e-book production in the service of textual scholarship and preservation. ${ }^{6}$ While the technology itself has become invisible with regard to the reading of written texts via e-books, the materiality of which is now studied by book historians, ${ }^{7}$ digitization creates distance and marks discontinuity whenever the

5 For the digitization of Islamic art, see for example the Yousef Jameel Projekt at the Museum für Islamische Kunst in Berlin, which is accompanied by a blog: http://jameel.hypotheses.org/; the digital surrogates are accessible via the database SMB-digital: http://www.smb-digital.de/eMuseumPlus. For a reflection on how the experience and understanding of three-dimensional mobile objects, that is: books, is changed, when they are accessed as a series of two-dimensional digital scans, see: David McKitterick, Old Books, New Technologies: The Representation, Conservation and Transformation of Books since 1700 (Cambridge: Cambridge University Press, 2013), 1-26.

6 See, for example: Eva Mroczek, "Thinking Digitally about the Dead Sea Scrolls: Book History before and beyond the Book." Book History 14 (2011): 241-269.

7 See, for example: Alex Galey, "The Enkindling Reciter: E-Books in the Bibliographical Imagination," Book History 15 (2012): 211-247. 
technology is employed to transform written texts and physical books into digital files in order to enable the application of computational research methods. For example, scholars need digitized manuscripts and printed books in order employ digital paleography, text mining, or distance reading in their research.

A critical reflection on the digitization of manuscripts and printed books in Arabic script has to begin with the fact that neither Book History nor the Digital Humanities (DH) are well-established subfields in Middle Eastern and Islamic Studies. ${ }^{8}$ The recent material turn in the Humanities ${ }^{9}$ has generated a growing interest in the cultural history of the manuscript book in Muslim societies, ${ }^{10}$ and scholars of Middle Eastern and Islamic Studies write influential blogs and maintain popular social media accounts such as Facebook and Twitter. The extent to which in the Middle East and North Africa electronic word processing has impacted book production can be gauged from the lavish appendices that have become a distinctive feature of academic books published, for example, in Egypt, Lebanon, and Iran. Considering the amazing power of relatively straightforward full-text search engines for text files, it is now customary to find in printed scholarly books, which presses often also issue as pdf-files, computer-generated indices for personal names, tribal names, place names, Quran verses, first lines of classical poetry, and so forth. But the available public information about digitization projects for material in Arabic script tends to be praise that foregrounds the number of pages newly digitized. ${ }^{11}$ The focus on countable, though not always comparable, units probably reflects the pressure of sponsors and grant-making agencies that need concrete outcomes in order to justify their funding decisions.

8 The 48th meeting of the Middle East Studies Association of North America (MESA), held from 22-25 November 2014 in Washington, DC, offers a representative case study. Ranjit Singh organized panel 009 on Social Media and the Arab Spring, while panel 016, organized by Sharon C. Smith and Sean E. Swanick, was dedicated to the politics of digitization and panel 080, organized by Rebecca L. Stein, explored the digitization of analog photographs vis-à-vis current practices in digital photography. With regard to Book History, panel 123 offered John Curry's roundtable on the publishing of a new sourcebook of medieval Middle East history, and panel 216 was organized by Kathryn Schwartz under the auspices of the Society for the History of Authorship, Reading and Publishing (SHARP). Yet events such as a Wikipedia Write-In or a THATCamp (http://thatcamp.org) did not take place in conjunction with the meeting. Even though this was the first MESA conference with the dedicated twitter hashtag \#MESA2014DC, conference tweeting was largely limited to announcements.

9 For an early reflection on the current popularity of Material History, see: Leora Auslander, Amy Bentley, Leor Halevi, H. Otto Sibum, and Christopher Whitmore, "AHR Conversation: Historians and the Study of Material Culture," American Historical Review 114, no. 5 (2009): 1354-1404.

10 For representative studies of book cultures in premodern Muslim societies, see: Antonella Ghersetti, ed., The Book in Fact and Fiction in Pre-Modern Arabic Literature (Special issue, Journal of Arabic and Islamic Studies 12, 2012); Nelly Hanna, In Praise of Books: A Cultural History of Cairo's Middle Class, Sixteenth to the Eighteenth Century (Cairo: American University in Cairo Press, 2003); Konrad Hirschler, The Written Word in the Medieval Arabic Lands: A Social and Cultural History of Reading Practices (Edinburgh: Edinburgh University Press, 2012); and Houari Touati, L'armoire à sagesse: Bibliothèques et collections en Islam (Paris: Aubier, 2003).

11 Typical recent examples are: Richard Davies, "Revealing Gulf History Online," British Library: Living Knowledge Blog, 2 December 2014, http://britishlibrary.typepad.co.uk/livingknowledge/2014/12/revealing-gulf-history-online.html; and Ursula Sims-Williams, "15,000 Images of Persian Manuscripts Online," British Library: Asian and African Studies Blog, 27 January 2014, http://britishlibrary.typepad.co.uk/asian-and-african/2014/01/15000-images-of-persian-manuscriptsonline.html. 
The impact of digitization on the preservation of cultural heritage in Muslim societies, ${ }^{12}$ or on its interaction with commercial publishing in Arabic script in Africa ${ }^{13}$ and Eurasia remains to be studied. Nor has digitization been applied to research challenges, such as the paleography ${ }^{14}$ of the Arabic script and the deciphering and analysis of illegible written texts. ${ }^{15}$ In general, scholars in Middle Eastern and Islamic Studies encounter digitization as an excellent tool for facilitating the access to literary content. ${ }^{16}$ We are dismayed if our sources are not yet conveniently available as digital surrogates, as it is now de rigeur that our research monographs are published as printed hardcovers for tenure and promotion, as well as in an electronic format with full-text search for ease of access and an affordable print-on-demand (POD) option for wider circulation. ${ }^{17}$

I find striking that there seems to be no expectation that in Middle Eastern and Islamic Studies we should get close-up and personal with the challenges posed by digitization with regard to the field's research infrastructure. Even though our grasp of the current situation will determine how we interact with both the underlying digital technology ${ }^{18}$ and the resulting digital surrogates in the future, ${ }^{19}$ we do not debate among ourselves which books and texts should be digitized and how long-term accessibility to their digital surrogates can be maintained for whom. ${ }^{20}$ In order to

12 Marilyn Deegan and Simon Tanner, "Conversion of Primary Sources," in A Companion to the Digital Humanities, eds. Susan Schreibman, Ray Siemens, and John Unsworth (Malden, Mass.: Blackwell, 2004), 488-504.

13 Digitization is not mention by Elizabeth le Roux, "Book History in the African World," Book History 15 (2012): 248-300.

14 For medieval French paleography, see: Marc H. Smith, "Numérisation et paléographie," Le médiéviste et l'ordinateur, no. 40 (Fall 2001): 9-16; http://lemo.irht.cnrs.fr/40/mo40-03.htm\#P180_31761.

15 See, for example, these prominent examples in the field of Classics: Melissa M. Terras, Image to Interpretation: An Intelligent System to Aid Historians in Reading the Vindolanda Texts (Oxford: Oxford University Press, 2006); and Reviel Netz, William Noel, Nigel Wilson, and Natalie Tchernetska, eds., The Archimedes Palimpsest (2 vols., Cambridge: Walters Art Museum, 2011).

16 Birte Kristiansen, "Digital Resources in Middle Eastern Studies," Bibliotheca Orientalis 71 nos. 3-4 (2014): cols. 388-400; and Ronald E. Kon, "Some Digital Resources for the Study of the Middle East," Bibliotheca Orientalis 71 nos. 3-4 (2014): cols. 400-403; the Netherlands Institute for the Near East has made this issue of Bibliotheca Orientalis available Open-Access (OA) at: www.nino-leiden.nl.

17 Brill's MyBook program offers moderately priced POD paperback copies of all hardcover books available via BrillOnline to those who are affiliated with an institution that subscribes to BrillOnline. 18 For the current debate among Digital Humanists on the relationship between $\mathrm{DH}$ and the Humanities, see, for example: Chun and Rhody, "Working the Digital Humanities, 1-25; Domenico Fiormonte, "Digital Humanities from a Global Perspective," Laboratorio dell'ISPF 11 (2014), doi: 10.12862/ispf14L203; and Alan Liu, "What is the Meaning of the Digital Humanities to the Humanities?" Proceedings of the Modern Language Association of America 128, no.2 (2013): 409-423.

19 For early reflections on the impact of digital surrogates and born-digital editions on the study of English literature, see: Jerome McGann, Radiant Textuality: Literature after the World Wide Web (New York: Palgrave, 2001), 53-74. For an early exploration of the potential of digital reference works, see: Alex Brymer Humphreys, "The Past, Present, and Future of Immersive and Extractive Ebooks," in Digital Media: Transformations in Human Communication, eds. Paul Messaris and Lee Humphreys (New York: Peter Lang, 2006), 159-172; a December 2004 version is available through the Social Science Research Network at: http://ssrn.com/abstract=1300567.

20 At the above mentioned MESA panel on the politics of digitization, participants explored the curious lack of critical scholarly involvement with digitization projects; for a panel description and the abstracts, 
better understand why we have so far preferred the role of consumers of e-books, electronic texts, or digital surrogates, I will explore first the relationship between writing and digitization, and then examine that between digitization and $\mathrm{DH}$. The essay will conclude with reflections on how to improve our engagement with digital surrogates, as it seems that for the time being digitization will remain the dominant technology for the copying of written texts.

My starting point is the observation that Islamic traditions of the transmission of knowledge favor a textual pragmatism which privileges the written text over the physical book. Despite the intense reliance on writing and literacy in all premodern Muslim societies, the ideal form of communication remained the personal encounter among human beings. ${ }^{21}$ From this perspective, the materiality of the physical book is secondary to the written word which in turn is secondary to the spoken word. ${ }^{22}$ It is one of the consequences of textual pragmatism that it separates the written text from the physical book in order to focus on literary content, while deflecting attention away from the physical books and the nitty-gritty economics of their manufacture, distribution, and maintenance. Since scholarship in Middle Eastern and Islamic Studies cannot but reflect the intellectual traditions of the Islamic civilization, textual pragmatism continues to dominate the field's textual scholarship in the early twenty-first century. The Muslim Middle East is praised as "one of the most bookish of pre-modern cultures," 23 and Islamic manuscripts are regarded as the most important resource for research on all aspects of Islamic civilization. The display of Islamic book culture in public exhibitions and the like is dominated by beautiful manuscripts from high-end workshops, ${ }^{24}$ even though Muslim societies had thriving book markets for middle-brow audiences, and the arts of the Islamic book also flourished with regard to the commercial manufacture of cheap books, whether their content was religious or secular. Yet research on physical books as material artefacts is primarily conducted by Islamic art historians, and textual scholars occupy themselves with written texts in

see:

https://mesana.org/mymesa/meeting_program_session.php?sid=e8557feb4e6e066a468dee5c17026fe8.

I am grateful to Sean E. Swanick for sharing with me his paper on "The Politics of Digitization: Islamic Materials and Digital Divide."

21 Franz Rosenthal, "'Of Making Books There is No End:' The Classical Muslim View," in The Book in the Islamic World: The Written Word and Communication in the Middle East, ed. George N. Atiyeh (Washington, DC: Library of Congress, 1995): "the never abandoned fiction [...] of the primacy of the spoken word" (35-36).

22 The understanding that books are surrogates of speech is not unique to Islamic civilization; see also: Donald F. McKenzie, Making Meaning: "Printers of the Mind" and Other Essays, eds. Peter D. McDonald and Michael F. Suarez (Amherst: University of Massachusetts Press, 2002): "a phrase like 'the impact of print'-however carefully it is qualified_cannot help but imply a major displacement of writing as a form of record. In the same way, too great a preoccupation with writing and printing (as the technologies of literacy) may lead us to forget the superior virtues of speech. After all, we did not stop speaking when we learned to write, nor writing when we learned to print, nor reading, writing or printing when we entered the 'electronic age'." (238).

23 Walid A. Saleh, The Formation of the Classical Tafsìr Tradition: The Qur'ān Commentary of al-Tha labī (d. 427/1035)(Leiden: Brill, 2004), 207.

24 The elite status of high-end manuscripts is nicely captured in the title of this exhibition catalog: Kjeld von Folsach, For the Privileged Few: Islamic Miniature Painting from the David Collection, Humlebæk, Denmark: Louisiana Museum of Modern Art, 2007. 
whatever format available. ${ }^{25}$ Source criticism and the editing of texts in Arabic script continue to be practiced as the ahistorical evaluation of content ${ }^{26}$ without any recourse to codicology, paleography, or bibliography, ${ }^{27}$ which, consequently, are not integrated into university curricula.

Against this backdrop I argue that the long intellectual tradition of textual pragmatism in the Islamic civilization informs our current interaction with electronic texts and digital surrogates. In Middle Eastern and Islamic Studies digitization is primarily applied to improve the access to literary content, as already mentioned, because the field is committed to textual pragmatism. On the one hand, we are comfortable with electronic texts and digital surrogates, since on a computer screen their literary content appears as immaterial and they are therefore experienced as authentic copies of written texts. ${ }^{28}$ The literary content's apparent immateriality veils, though, that authenticity is not an intrinsic characteristic of any digital file. Electronic texts and digital surrogates only seem authentic as long as the interference of computer technology, in particular the loss of information in different file formats, remains invisible to the readers who encounter them on their computer screens. ${ }^{29}$ On the other hand, as scholars we do not feel obliged to concern ourselves with the production of material artefacts, since textual pragmatism focuses on written texts, and not on physical books, whether they are manuscripts, printed books, or ebooks.

\section{Writing and Digitization}

And further, by these, my son, be admonished: of making many books there is no end; and much study is a weariness of the flesh.

Ecclesiastes 12:12

The title of this essay is a play on an article about medieval Muslim book culture by Franz Rosenthal (1914-2003). ${ }^{30}$ Written in the early 1990s, after more than five decades of reading sources from Late Antiquity to the nineteenth century, in a wide range of languages, Rosenthal

25 In editions prepared in Muslim societies, scholars distinguish between handwritten copy (Ar. alnuskhah al-khațtiyyah, Pers. kitāb-i khatți) and printed copy (Ar. al-nuskhah al-mațbūah, Pers. kitāb-i chābi), but since both are copies (Ar. sing. nuskhah, Pers. nuskhah) of texts, they are comparable irrespective of the differences between writing by hand (Ar. khatța, Pers. khatt kirdān) and printing (Ar. taba'a, Pers. chāb kirdān).

26 For a discussion of how twentieth-century editors rely on common sense (Ar. al-dhawq al-salim), without any recourse to critical bibliography and source criticism, see: Jan Just Witkam, "The Son's Copy: Remarks on a Contemporary Manuscript of Ibn 'Asākir's 'History of the City of Damascus',' in Maqālāt wa-dirāsāt muhdāh ilā Doktor Șalāh al-Dīn al-Munajjid (London: Furqan Foundation, 2002), 591-610. Witkam, however, describes "al-dhawq al-salimm" without offering an explanation for its acceptance as an editorial strategy.

27 See, for example, the description of eight manuscripts without any accompanying analysis of how these copies be related to each other and to the same Arabic text in: Hasan Ansari and Sabine Schmidtke, "The Literary-Religious Tradition among 7th/13th Century Yemenī Zaydīs: The Formation of the Imām al-Mahdī li-Dīn Allāh Aḥmad b. al-Ḥusayn b. al-Qāsim (d. 656/1258)," Journal of Islamic Manuscripts 2 (2011): 178-180.

28 Siân Echard, Printing the Middle Ages (Philadelphia: University of Pennsylvania Press, 2008), 202.

29 David McKitterick, Print, Manuscript and the Search for Order, 1450-1830 (Cambridge: Cambridge University Press, 2003), 18.

30 Rosenthal, "'Of Making Books'," 36. 
uses this famous and much debated verse from Ecclesiastes to illustrate an easily overlooked consequence of writing as a technology for the preservation of the spoken word: the unlimited reproducibility of the written word on whatever writing surface available, makes it much harder to distinguish between new written texts and copies, or variations, of old written texts. Since books were - especially if seen from the vantage point of a rich western society in the early twenty-first century - a rare commodity in all premodern societies, the incentive to produce ever more copies of books was even greater. Rosenthal's insight is so startling because in general we rarely distinguish between a book as material artefact and its literary content. Consequently, the metonymy of using "book" for "text" is no longer recognizable as a rhetorical sleight of hand.

Approaching books as a reproducible commodity—comparable to luxury goods like Rolex watches and Tiffany jewelry which circulate as expensive originals and in a variety of cheap spinoffs and outright fakes-allows for taking the long view which, in turn, brings into focus that digitization as a means for the cost-efficient production of new copies of written texts does not constitute a rupture in the history of the book. The reproducibility of the physical book in order to preserve its literary content is integral to books, since no material artefact will last foreverwhether it is kept as protected cultural heritage in a customized depository or whether it is stored as a digital file on multiple servers. Dedicated professionals have produced new copies of written texts for readers since the third millennium BCE when Sumerian scribes preserved Mesopotamia's literate knowledge through the copying of cuneiform tablets. ${ }^{31}$ In a microhistorical perspective, an examination of digitization as an isolated phenomenon will reveal its dramatic impact on the scale of book production during the last two decades. But in a macrohistorical perspective, the number of copies in which a text circulates among audiences has continually increased, with each new technological invention: from scroll to codex, from papyrus to rag paper, from letterpress printing to lithography, from typewriter to personal computer. In each instance, the application of a new technology to commercial book production has also reflected economic pressures, since one of the drivers of technology adaptation is the goal of cost-efficient production to ensure continuing financial viability and commercial profitability. ${ }^{32}$

The 1980s rise of the "what you see is what you get" (WYSIWYG) systems for word processing and desktop publishing ${ }^{33}$ has ensured that nowadays most readers distinguish a file with a digitized manuscript or rare printed book from a file with a new and unpublished piece of writing solely on the basis of their content, since text encoding and markup are only visible to those who know where to look for them. At the same time, editors expect that authors submit their manuscripts electronically as digital files, since the publishing industry has employed electronic word processing machines since the early 1960s. ${ }^{34}$ The continued use of the anachronism "manuscript" for an author's unpublished work is noteworthy, since already in the twentieth

31 Eleanor Robson, "The Clay Table Book in Sumer, Assyria, and Babylonia," in A Companion to the History of the Book, eds. Simon Eliot and Jonathan Rose (Malden, Mass.: Blackwell, 2007), 71.

32 Paul Luna, "Books and Bits: Texts and Technology 1970-2000," in Companion to the History of the Book, eds. Eliot and Rose: "changes in text composition were driven by economic imperatives, first to reduce the cost of turning an author's text into publishable data, and subsequently to extract maximum value from that data." (381).

33 Allen H. Renear, "Text Encoding," in Companion to the Digital Humanities, eds. Susan Schreibman et al., 229-230.

34 Luna, "Books and Bits," 383. 
century typescripts had for the most part replaced manuscripts in longhand. ${ }^{35}$ The resilience of the concept of an "author's manuscript" in the digital age indicates that in general a book's literary content receives more attention that its materiality. ${ }^{36}$ This reflexive, though nonetheless acquired focus on a book's written text makes it much harder to discern the different socioeconomic circumstances of book production, which are documented by the material differences between manuscripts, printed books, and e-books. ${ }^{37}$

During the last decade, readers in industrialized societies have witnessed courtesy of Google, Apple, and Amazon the rise and the naturalization of the e-book on hand-held devices, such as a smartphone, tablet, or Kindle, as well as on rather old-fashioned personal computers (Figures 1-3). At the same time, libraries in Europe and North America, as well as in North Africa and the Middle East are continuing with large-scale digitization projects to fulfill their national mandates of providing citizens with Open-Access $(\mathrm{OA})$ to their cultural heritage. In Europe and North America, prominent examples of these efforts are the Online Gallery of the British Library (Figure 3), ${ }^{38}$ Gallica at the Bibliothèque nationale de France, ${ }^{39}$ or the recently opened Digital Public Library of America. ${ }^{40}$ The Bibliothèque Nationale du Royaume du Maroc is working on making within the next few years all its manuscripts and lithographs available via the Bibliothèque Numerique Marocaine. ${ }^{41}$ This summer saw the long awaited launch of the ArabicEnglish Qatar Digital Library, ${ }^{42}$ which includes Arabic manuscripts. Iran maintains an online database of digitized manuscripts which is named after the bibliographer Shaykh Āqā Buzurg Tihrānī (1293-1389/1876-1970).43 All manuscripts of the Süleymaniye Library in Istanbul are now digitized, but these digital surrogates can only be accessed on the computer terminals in its reading room. ${ }^{44}$ The Bibliotheca Alexandrina in Egypt cooperates with the Internet Archive (IA)

35 In the early 1990s, an author's handwriting was only discussed in connection with regard to mathematical copy in The Chicago Manual of Style (14th ed., Chicago: University of Chicago Press, 1993), 438 para. 13.17.

36 As explicitly stated in The Chicago Manual of Style (16th ed., Chicago: University of Chicago Press, 2010): "The industry-wide goal for e-book versions of printed monographs has been one of approximation on screen the experience of reading the printed book. The discussion on the parts of a book-though it assumes electronic publication is an option for any scholarly book-therefore includes special considerations for electronic book formats only where these might differ from those for print." (4, para. 1.2).

37 McKenzie, Making Meaning. "the richness of evidence that all textual forms themselves contain and [...] the skilled labour that went into the choice of their materials, design, and execution. The signs that we read in the artefacts we keep tell us of lives lived by men and women who had identities just as distinct and valuable as our own. The point that I am making is fundamental to any history of the book which would seek to derive its primary evidence from original artefacts as products of distinctive contexts and yet also demonstrate their successive transformations in response to new needs." (271).

38 http://www.bl.uk/onlinegallery/virtualbooks/index.html.

39 http://gallica.bnf.fr/.

$40 \mathrm{http}: / / \mathrm{dp} . \mathrm{la} /$.

41 http://bnm.bnrm.ma:86/Accueil.aspx; for a history of the digital depository and its work schedule, see:

"À propos de la Bibliothèque Numerique Marocaine," http://bnm.bnrm.ma:86/apropos.aspx [accessed 3 December 2014].

42 http://www.qdl.qa/en.

43 Shaykh Āqā Buzurg Tihrānī: Bānk-i ițtilāāăt-i nusakh-i khaț̣ī: http://www.aghabozorg.ir/.

44 Nir Shafir and Christopher Markiewicz, "Süleymaniye Library," Hazine (blog), 10 October 2013, http://hazine.info/suleymaniye-library/. 
in order to create and maintain its Arabic Digital Assets Repository (DAR), ${ }^{45}$ but rare printed books and manuscripts, as well as a collection of digital surrogates, are kept in the Manuscript Museum. ${ }^{46}$ These national projects are complimented by international initiatives, which rely on digitization in order to preserve endangered collections of both manuscripts and printed books in Afghanistan, ${ }^{47}$ Yemen, ${ }^{48}$ West Africa, ${ }^{49}$ and Iraq. ${ }^{50}$ Manuscripts and printed books, though often only illuminated single leaves, are also included into all digitization projects at museums worldwide. ${ }^{51}$

The steadily increasing availability of digital surrogates and e-books veils the economic fact that each digitization project places a significant financial burden unto an institutional budget. Since the interpretation of digital surrogates depends on the understanding of how two-dimensional images represent three-dimensional material artefacts, ${ }^{52}$ digital surrogates cannot replace material artefacts, and best practice now requires that repositories maintain both the material artefacts and their digital surrogates. Consequently, digitization projects are not cost-neutral undertakings. Nor is the maintenance of digital surrogates and e-books cheaper than the conventional storage of physical books. ${ }^{53}$ The growth of an institution's digital resources, whether they are digital surrogates or e-books, usually involves difficult decisions about the deaccessioning and defunding of other holdings and services. ${ }^{54}$ As regards the environmental

45 For an undated statement about the cooperation, see: https://archive.org/about/bibalex_p_r.php [accessed 11 February 2015]. The repository is under construction, and currently only accessible via a beta version at: http://dar.bibalex.org/webpages/dar.jsf [accessed 11 February 2015].

46 Matḥaf al-makhțūtāt, http://manuscriptsmuseum.bibalex.org/.

47 Afghanistan Digital Library: http://afghanistandl.nyu.edu/; this project provides OA to all its website statistics in real time: http://dl-pa.home.nyu.edu/adlstats/adl.

48 Yemeni Manuscript Digitization Initiative (YMDI): http://pudl.princeton.edu/collections/pudl0079; see also the project description by David Hollenberg at: http://ymdi.uoregon.edu/.

49 Federal Foreign Office, "Außenminister Steinmeier eröffnet internationales Strategietreffen zum Erhalt der Handschriften aus Timbuktu," press release, 17 June 2014; http://www.auswaertiges-amt.de/DE/Infoservice/Presse/Meldungen/2014/140617Strategietreffen_Kulturerhalt.html [accessed 2 December 2014].

50 Nikki Rajala, "HMML Makes Ancient Manuscripts Accessible to Scholars Worldwide," The Visitor102, no. 23 (7 November 2014): 3; http://visitor.stcdio.org/hmml-makes-ancient-manuscripts-accessiblescholars-worldwide/ [accessed 2 December 2014].

51 A search of databases such as the Google Cultural Institute (https://www.google.com/culturalinstitute/home) and the Wikimedia Commons (http://commons.wikimedia.org/wiki/Main_Page) will reveal a wide range of digital images of manuscripts and printed books uploaded by public and private institutions, as well as individual citizens, worldwide.

52 For a description of this problem within the context of computational image analysis, see: Kohle, Digitale Bildwissenschaft, 70-72.

53 Several units of measurement—cataloging record, title, and page-are provided in the assessment of the Islamic Heritage Project at Harvard University by Chapman, "The Harvard University Library Islamic Heritage Project," 19 and 27. Yet none of these can be related to the annual fee of managed storage and digital preservation services of $\$ 2.50$ per gigabyte which Harvard's Digital Repository charged between 2007 and 2009, when the digital surrogates were produced.

54 McKitterick, Old Books: "The costs of libraries in our own world, with all their complexities and challenges, are still only partially grasped." (3); and "At every level, from school libraries to public libraries to university libraries to learned societies and to national libraries, books are being discarded and destroyed at an unprecedented rate." (212). 
impact of digitization, grant-making agencies such as the European Research Council (ERC) and the National Endowment for the Humanities (NEH) expect applicants to develop data management plans and dissemination strategies, but they do not yet require a discussion of their project's carbon footprint. ${ }^{55}$

Unfortunately, the complexity of digitization projects and electronic publishing is invisible to readers, as a few keystrokes on a keyboard are all that is needed to open the pages of an Islamic manuscript or a printed book on a computer screen. ${ }^{56}$ This cognitive dissonance is reinforced by a mode of distant access that ideally requires no direct interaction with other human beings: we double-click on digital surrogates and e-books on our computer screens in the privacy of our homes and offices, and no longer negotiate with librarians over how to use the material artefacts in library reading rooms. Consequently, it seems counterintuitive that the long-term use of digital surrogates and e-books will depend not only on the continuous upgrading of hardware and software but also on the availability of human labor dedicated to the maintenance of efficient digital delivery systems. ${ }^{57}$ That digitization projects rarely create permanent jobs is one of the reasons why David McKitterick recently observed that "scanning programmes are built on weak foundations" and "too often show lamentable quality control." 58

The high costs of digitization projects are mitigated by grant-making agencies which offer competitive funding opportunities for the access to hidden collections and the preservation of endangered ones. ${ }^{59}$ Since governments are underwriting digitization projects, they are also prestigious undertakings for private sponsors. From a fundraising perspective, digitization projects are attractive propositions for wealthy individuals, since digital surrogates can be made available as OA resources which, thanks to their ethereal appearance on our computer screens, seem to have no tangible connection to contentious political debates on research funding and labor politics in the Humanities. ${ }^{60}$ Indeed, philanthropists and private foundations are

55 The curious silence about the environmental impact of digitization vis-à-vis print publications on paper could be considered an instance of "the vapid embrace of the digital" as discussed by Chun and Rhody, "Working the Digital Humanities," 3.

56 For a reflection on why Humanists and Digital Humanists alike need to actively concern themselves with the accounting and budgeting modes of their institutions, in particular with regard to overhead calculations in grant administration, see: Chun and Rhody, "Working the Digital Humanities," 10-12, 16, 19.

57 Deegan and Tanner, "Conversion of Primary Sources": "Understanding the capture processes for primary source materials is essential for humanists intending to engage in digital projects, even if they are never going to carry out conversion activities directly. Knowing the implications of the various decisions that have to be taken in any project is of vital importance for short- and long-term costs as well as for the long-term survivability of the materials to which time, care, and funds have been devoted." (502).

58 McKitterick, Old Books, 9.

59 The most prominent initiatives in the Anglo-American context are probably the Hidden Collections Program of the Council of Library and Information Resources (http://www.clir.org/hiddencollections), and the Endangered Archives Programme of the British Library (http://eap.bl.uk/). For the financial challenges which small repositories face with regard to providing access to insufficiently cataloged holdings, see: Sheila A. Bair and Susan M. B. Steuer, "Developing a Premodern Manuscript Application Profile Using Dublin Core," Journal of Library Metadata 13, no. 1 (2013): 2-3.

60 In Western Europe and North America, the irrelevance of the Humanities has received much political attention since the early 1980s. For an introduction to the 1980s debate in the US, see: David Bromwich, Politics by Other Means: Higher Education and Group Thinking (New Haven: Yale University Press, 
indispensable supporters of the digitization of manuscripts in Arabic script, and, in general, privately funded projects are exposed to less public scrutiny. In contrast, taxpayer funded projects are closely monitored in order to ensure that these projects fulfill their public mandates, and detailed information about their work is available in the public record. Still, protecting and championing the cultural heritage of a more or less exclusively defined community is often among the publicly stated goals of private sponsors. The Thesaurus Islamicus Foundation, which is the mother of The Islamic Manuscript Association (TIMA), runs the Dar al-Kutub Manuscript Project in Cairo, though an explicit digitization project is not publicly identified. ${ }^{61}$ Other private sponsors are the Imam Zayd Cultural Foundation, ${ }^{62}$ the Iran Heritage Foundation (IHF), ${ }^{63}$ Yousef Jameel, ${ }^{64}$ and Prince Alwaleed Bin Talal. ${ }^{65}$ They are funding several digitization projects in public and private collections in Europe and North America, thereby reclaiming manuscripts, as well as other material artefacts, as their respective cultural heritage. It depends on the mission of the respective private sponsor to which degree the resulting digital surrogates are also intended as means to the end of giving a boost to particular religious and political goals.

\section{Digitization and DH}

Question: How many Digital Humanists does it take to change a lighbulb? Answer: Two. The first to change the lightbulb using the available, existing technology. The second to say "You are not DH unless you make the lightbulb yourself."

Melissa Terras' Blog, blog entry, 8 April 2013

Digitization has an ambiguous status within $\mathrm{DH}$ : it is associated with access and electronic publishing, and allows for the application of digital tools to datasets. The latter is a scholarly pursuit, whereas the former concerns communication and outreach. Digital Humanists discuss the respective merits of digital and analog methods of disseminating knowledge, because computational methods of analysis often generate research data that cannot be meaningfully represented in print. ${ }^{66}$ But digitization is primarily presented as a conversion tool which allows for the generation of hitherto unimaginable corpora of digitized written texts and images. This quantitative increase is adduced as the main argument whenever Digital Humanists describe digitization as a disruptive tool and champion its potential for the pursuit of a progressive

1992). For a glimpse of the current debate in the US, see: Christopher Benfey, "How Bad Are the Colleges?" New York Review of Books, 23 October 2014, 14-18.

61 http://www.thesaurus-islamicus.org/.

62 www.izbacf.org/.

63 http://www.iranheritage.org/organisation.htm; the IHF's Persian Manuscript Digitization Project at the British Library is available at: http://www.iranheritage.org/BL_Project/.

64 For an authorized official biography, see: $\mathrm{http} / / / j a m e e l c e n t r e . a s h m o l e a n . o r g / p r o j e c t / 21$.

65 For the Harvard University Library Islamic Heritage Project (http://ocp.hul.harvard.edu.ihp), see: Stephen Chapman, "The Harvard University Library Islamic Heritage Project: Challenges in Managing Large-Scale Digitization of Islamic Manuscripts," Journal of Islamic Manuscripts 1 (2010): 18-30.

66 Susan Schreibman, Ray Siemens, and John Unsworth, "The Digital Humanities and Humanities Computing: An Introduction," in Companion to the Digital Humanities, eds. Susan Schreibman et al.: "The field also places great importance on the means of disseminating the results of these activities" (xxv); cf. Chun and Rhody, "Working the Digital Humanities," 9. 
research agenda. ${ }^{67}$ At the same time, many $\mathrm{DH}$ studies are published as traditionally printed books on paper, and not of all of these are complimented with an OA version on the Internet. ${ }^{68}$ Digital Humanists can rely on digitized sources and electronically publish their research without having to confront the economics of either digitization projects or electronic publishing, even though in every research infrastructure - whether local, national, transnational, or internationalthe financial resources for providing OA to sources, as well as research and reference, are finite. 69 Since the limitation of the available resources for digitization seems to contradict our concrete experience of being surrounded by e-books and digital surrogates, there is not any debate about the obvious fact that we have neither the financial nor the human resources to digitize even every manuscript, printed book, or document held in special collections right now. ${ }^{70}$ As there is no recognition of our limited resources, there is also no debate about priorities and selection criteria, and we do not know how that what is available as digital surrogate is related to extant holdings in private and public repositories.

This situation reflects in part economic iniquities in academia. Scholars with gainful employment at well-funded research institutions are shielded from exposure to the financial realities of both $\mathrm{OA}$ and restricted access to proprietary digital resources, such as bibliographies, encyclopedias, critical editions, databases of literary sources, and research publications. Whenever comprehensive library privileges are a crucial employment benefit, scholars can concentrate on their research and do not need to spend precious time on getting hold of sources and scholarship. ${ }^{71}$ Conversely, independent scholars and those working at institutions with limited resources ${ }^{72}$ are so dependent on the generosity of others that they rather not question how sources and scholarship are made available as OA. ${ }^{73}$

67 For quantitative methods in history, see: Jo Guldi and Richard Armitage, History Manifesto (Cambridge: Cambridge University Press, 2014), 93, 153 n. 12; and 113, 159 n. 64. For the value of large data sets in art history, see: Kohle, Digitale Bildwissenschaft, 9-11 and 76-95.

68 Guldi and Armitage, History Manifesto, doi: http://dx.doi.org/10.1017/9781139923880; and Kohle, Digitale Bildwissenschaft, doi: http://archiv.ub.uni-heidelberg.de/artdok/volltexte/2013/2185.

69 For the failed Gutenberg-e dissertations project (1999-2003) of the American Historical Association and Columbia University Press, see: http://www.gutenberg-e.org/aboutframe.html.

70 Mckitterick, Old Books: "It is improbable that there will ever be a time when all the books that have ever been published, and that survive, will be available electronically." (9); cf. the parallel universe of an eternal library that houses all books of humankind in: Jorge Luis Borges, "The Library of Babel," in Collected Fictions, trans. Andrew Hurley (London: Penguin, 1998), 112-118.

71 For a recent survey of the economic challenges in academic publishing, see: Robert Darnton, "The World Digital Library Is Coming True," New York Review of Books, 22 May 2014, 8-11; and the subsequent exchange between Darnton and Robert A. Schneider, "Overpriced Scholarship," New York Review of Books, 6 November 2014, 56-57.

72 Not every college or university can afford its own OA repository of research publications; cf. Digital Access to Scholarship at Harvard (http://dash.harvard.edu/) and the Academic Commons of Columbia University (http://academiccommons.columbia.edu).

73 Not all written texts and material artefacts, whose digital surrogates are available OA on the Internet, are also available for a free download. For example, those who are not associated with an institutional member of the HathiTrust Digital Library (http://www.hathitrust.org/) have limited access to its resources (Figure 2), though the University of Michigan offers the possibility of enhanced access via a "Friend Account;" see: http://www.hathitrust.org/help_digital_library\#FriendAccount. 
For scholars working in Europe and North America economic iniquities in academia determine their ability to conduct research, but economic iniquities do not explain why the engagement with $\mathrm{DH}$ varies so greatly between academic disciplines. In Middle Eastern and Islamic Studies there are very few scholars who have at least one foot firmly planted into computer science or electric engineering and could thus be considered genuine Digital Humanists. Moreover, the digital divide in Muslim societies goes largely unnoticed, ${ }^{74}$ even though the recent democratic protest movements in Iran, Tunisia, Egypt, or Turkey have ensured that the political impact of social media is now widely studied. Despite the harrowing news reporting about violence, poverty, and underdevelopment in Muslim societies, their perception is dominated by the actions of either westernized elites or Islamist terrorists. Both groups are committed Internet users, though primarily as consumers who are interacting with digital tools like smart phones and computers. DH as an academic discipline has not yet taken root at most institutions of higher learning in the Middle East and North Africa. ${ }^{75}$ Its integration into university curricula is facilitated via disciplines such as English Studies, which have embraced DH since the 1990s, and prestigious institutions, such as the American University of Beirut (AUB), are now developing $\mathrm{DH}$ programs. ${ }^{76}$

Taken together, these observations indicate that Middle Eastern and Islamic Studies is not a good match for $\mathrm{DH}$. While our research questions respond to present-day concerns, our approaches are still reflecting the intellectual traditions of the Islamic civilization. Computational methods of analysis are of little use to a field that is committed to textual pragmatism, even if digital copies of written texts are experienced as a very convenient way of obtaining access to literary works. That this cognitive dissonance in Middle Eastern and Islamic Studies is not particular to how we have adapted to the digital age is indicated by a textbook, like Stephen Humphreys' widely used introduction to the study of Islamic history. Humphreys wrote his vademecum in the late 1980s for graduate students at North American universities. ${ }^{77}$ Although an updated English edition was never published, a Turkish translation appeared in $2004 .{ }^{78}$ The book begins with an analytical survey of the sources of Islamic history, and Humphreys opens the chapter with the observation that scholars of the Muslim Middle East "like to complain about the state of their sources, but in fact what they have is extraordinarily rich and varied." 79 Regrettably Humphreys did not venture any explanation why Islamic historians do not have a happy relationship with their sources, even though his introduction is a practitioner's guide to historical research about Muslim societies. The reader receives instead the sensible advice that the effective use of sources depends on asking good questions which in turns demands

\footnotetext{
74 The ubiquity of cellphones veils the digital divide to some degree; see for example the description how illiterate Cairenes rely on help in order to receive texts on cellphones in: Peter Hessler, "Tales of the Trash: A Neighborhood Garbageman Explains Modern Egypt," New Yorker, 13 October 2014, 96-97. 75 The situation of DH in South Asia seems to reflect the importance of India's high-tech industry, as well as the role of English, despite its colonial origins, as an indispensable lingua franca.

76 For AUB's first DH workshop, organized by the Department of English in 2013, see: http://www.aub.edu.lb/FAS/ENGLISH/Pages/DigitalHumanitiesatAUB.aspx; for Beirut's new DH Institute, see: https://dhibeirut.wordpress.com; and for the first THATCamp in the Middle East, see: http://beirut2015.thatcamp.org/.

77 R. Stephen Humphreys, Islamic History: A Framework for Inquiry (Princeton: Princeton University Press, 1988, rev. ed.,1991); all references are to the 1991 edition.

78 Islam tarih metodolojisi: Bir sosyal tarih uygulaması, trans. Murtaza Bedir and Fuat Aydın (Istanbul: Litera, 2004); non vide.

79 Humphreys, Islamic History, 25.
} 
knowing these sources. Nor did Humphreys pause to reflect on the question of why access to manuscripts in Arabic scripts was, and has remained, difficult and time consuming. ${ }^{80}$ The reader is merely warned that her research was likely to include the work with manuscripts in Arabic script as a matter of necessity, since not all sources were available in printed versions. ${ }^{81}$ Crucial to becoming and being a historian of Muslim societies was therefore the unconditional commitment to plodding through printed bibliographies and catalogs in order to hunt down manuscripts and rare printed books. Humphreys recommended the use of a personal computer with good citation software to get on top of the field's bibliographic challenges, but the indispensable reference works and bibliographies were printed books. ${ }^{82}$

In hindsight it is stunning that Humphreys saw no need to include even a cautionary note that computer science would probably continue to change the methods of finding and accessing sources and scholarship. After all, in Europe and North America, digital technology has directly impacted library and information science for about half a century. As already mentioned above, publishers started to experiment with computer-assisted composition and printing in the early 1960s. ${ }^{83}$ The beginnings of OCLC/WorldCat as a computer-based cataloging network in Ohio go back to the mid-1960s. ${ }^{84}$ CD-ROMs, euphorically described as "the new papyrus," have been used for electronic publishing since the mid 1980s. ${ }^{85}$ Since the late 1980s students and faculty in North American research universities were directly experiencing the impact of computer science on their research. Online library catalogs were available to search for books not available in their own institutions while databases of digitized texts on CD-ROMs offered access to texts not available as manuscript, printed book, or microfilm resp. microfiche. Against this backdrop, Humphreys' technological expectations with regard to the written sources of Islamic history were very modest indeed. He appreciated the Arab League's collection of photographed manuscripts, ${ }^{86}$ but dismissed microfilms as "no substitute for the real thing." 87

Humphrey's hands-on attitude, however, reflects the peculiar situation of Middle Eastern and Islamic Studies within the Humanities in Europe and North America. The first characteristic of this situation is easy to miss, because it seems such a non-issue: size. Middle Eastern and Islamic Studies field is not as large as History, but it is also not as small as Ancient Near Eastern Studies. From the perspective of the second decade of the twenty-first century, it has become much easier to recognize how scale is crucial for the approaches taken by a particular field as a whole toward the adaptation of electronic research methods and independent online publishing. In small fields the embrace of $\mathrm{DH}$ reflects in part the need to get the most out of very limited resources. As it is very difficult to sustain the publication of reference works, editions, and research monographs in small fields, there is no downside to effective data sharing across national borders and continents via OA. Even though research budgets have been steadily shrinking for more than a decade across the Humanities as well as the Sciences,

80 Cf. the difficulties of a field like $\mathrm{DH}$ to embrace failure as a disciplinary value, as discussed by Chun and Rhody, "Working the Digital Humanities," 4-5, 15-16.

81 Humphreys, Islamic History, 32-40.

82 Humphreys, Islamic History, 7.

83 Luna, "Books and Bits," 383.

${ }^{84}$ Charles Chadwyck-Healy, "The New Textual Technologies," in Companion to the History of the Book, eds. Eliot and Rose, 453.

85 Chadwyck-Healy, "New Textual Technologies," 458.

86 Humphreys, Islamic History, 27.

87 Humphreys, Islamic History, 36. 
large fields in the Humanities have still more institutional resources and more researchers than smaller fields, and so for them it remains easier to hedge against the risk of failure that always accompanies change and innovation. The middling size of Middle Eastern and Islamic Studies in western academia appears thus as one of the reasons why there are not yet tenure-track positions for Digital Humanists in Middle Eastern and Islamic Studies departments, when there are already tenured Digital Humanists in departments with large faculties, such as English and History. The limited resources available for DH in Middle Eastern and Islamic Studies are likely a contributing factor why projects for the digitization of manuscripts in Arabic script have not yet spawned a digital paleography of the Arabic script or the development of a proven Optical Character Recognition (OCR) technology for languages written in the Arabic script. On list services dedicated to Middle Eastern and Islamic Studies, there are regularly requests for pdffiles of Arabic or Persian texts with full-text search, and yet there are no debates how full-text search is enabled. How often should a text be independently keyed in to achieve a modicum of accuracy and which markup language should be used?88 While some may argue that list services dedicated to Arabic literature, the medieval Middle East or the sociology of Islam are the wrong places for such technical debates, digital paleography, OCR technology, and markup languages such as the Text Encoding Initiative (TEI) are popular themes in the DH community.

A second factor that is important for the successful integration of $\mathrm{DH}$ into a field's research program is its "scholarly infrastructure." 89 Humphreys, in a surprisingly emotional aside, considered it "a disgrace and a serious inconvenience" that bibliographers in Europe and North America never established "a regular, systematic survey of scholarly books and articles published in Arabic, Persian, Turkish and Urdu."90 In fields such as the study of Greco-Roman antiquity or English literature, Humanities computing provides scholars, who already have wellestablished standards and citation schemes for large research libraries of primary and secondary sources, the tools for both access to sources and research about the sources. Unfortunately, such a scholarly infrastructure is not in place in Middle Eastern and Islamic Studies, where textual criticism is shunned because it is identified with philology as the essence of Orientalist scholarship. ${ }^{91}$ Textual pragmatism, though, seems at least in part supported by the Saidian critique of and opposition to philology. Even though this line of reasoning rests on a false syllogism, ${ }^{92}$ it explains our hands-off attitude regarding textual criticism. But it is not only an expression of our post-colonial rejection of philology that we remain silent about the textual condition of our written sources. The scholarly commitment to textual pragmatism unites an often quite factionalized discipline, since scholars working in Europe and North America can share this commitment with their colleagues in the Muslim societies of Eurasia and Africa. The

88 Both the desideratum of a proven OCR technology for the Arabic script and the high labor costs for keying in and marking up a full text are obliquely mentioned by Chapman, "Harvard University Library Islamic Heritage Project," 26-27.

89 Greg Crane, "Classics and the Computer: An End of the History," in Companion to the Digital Humanities, eds. Schreibman et al., 46.

90 Humphreys, Islamic History, 7. That the situation did not significantly improve between the late 1980s and the 2000s is suggested by Andrew Rippin's observation of a "loose control over the reprinting of works by different publishers in many parts of the Arab world" ("Preface," in The Blackwell Companion to the Qur'ān, Blackwell Reference Online, 2008, doi: 0.1002/9780470751428.fmatter).

91 Edward W. Said, Orientalism (New York: Vintage, 1979): "Almost without exception, every Orientalist began his career as a philologist," (98).

92 The false syllogism equates textual criticism with philology, and philology with Orientalism. 
still indispensable bio-bibliographical reference works by Carl Brockelmann (1868-1956), ${ }^{93}$ C. A. Storey (1888-1968), ${ }^{94}$ and Fuat Sezgin (b. 1924) ${ }^{95}$ provide systematic catalogs of the major works of Arabic and Persian literature, in which manuscripts and printed books are not separated from each other. Accordingly, any random sampling of Middle Eastern and Islamic Studies dissertations, which were accepted during the last two decades at US universities, will yield odd bibliographical references for manuscripts which indicate that research committees did not worry about different citation standards for manuscripts and printed books, respectively. In Muslim societies, there are many websites that offer free access-in a range of formats, though with a slight preference for downloadable pdf-files - to various corpora of Arabic, Persian, Ottoman, or Urdu literatures. ${ }^{96}$ Their number has been steadily increasing since the late 1990s. Routine references to these online libraries on list services show that they are widely used by scholars, even though many are rather collections of gray literature. ${ }^{97}$ The texts are usually not accompanied by comprehensive cataloging, and their legal status in terms of digital rights management (DRM) is treated as moot. 98 Their wide acceptance inside and outside academia illustrates the efficiency of textual pragmatism in the digital age, since the adaptation of digitization to bookmaking is not hampered by theoretical concerns for the ontological differences between original and copy. In other words, the historicist awareness for the differences between material artefacts, their facsimiles, and their forgeries is as irrelevant as legal concerns about copyright law and best practices in $\mathrm{DH} .99$ As long as we remain committed to textual pragmatism, we will assume that literary works are preserved as stable written texts so that it does not matter in which medium they are reproduced and can be read. 100

\section{Digitization and Access to the Cultural Heritage of Muslim Societies}

Be explicit about your goals and your criteria, record your every doubt and misstep, and aspire to be remembered for the ignorance that was uniquely yours, rather than for the common sense you helped to construct.

93 Geschichte der arabischen Litteratur: Grundwerk (2 vols., 1st ed., Weimar: Felber, 1898-1902; 2nd ed., Leipzig: Amelang, 1901) and Supplementband (3 vols., Leiden: Brill, 1937-1942).

94 Persian Literature: A Bio-Bibliographical Survey (1/1-, London: Luzac, 1927-).

95 Geschichte des arabischen Schrifttums (1-, Leiden: Brill, 1967-).

96 For annotated lists of primary source material and web-based resources, see: Kristiansen, "Digital Resources," cols. 396-400; and Kon, "Some Digital Resources," cols. 401-403.

97 For a reflection on the digital archives of Islamic literatures from a user's perspective, see Travis Zadeh's contribution to this volume.

98 See for example: L. W. C. van Lit. "Full-Text Online Arabic Sources: A Preliminarv List." The Diaital Orientalist (bloq). 16 Januarv 2015. http://diaitalorientalist.com/2015/01/16/full-text-online-arabic-sourcesa-preliminarv-list/. Van Lit provides a list of six restrictions accordina to which he combiled a list of 21 OA internet depositories. but these restrictions do not extend to a depositorv's leaal status (e.a.. copvriaht) and the securitv of its website (e.a.. virus infection). Noteworthv is furthermore that van Lit's list excludes depositories of scanned images as they presumably do not offer full-text search.

99 See David Hirsch's report about his 2012 workshop for Iraqi librarians in: TAR/I Newsletter 8, no. 1 (2013): 22; available at: http://www.taarii.org/images/PDF/08-01.pdf.

100 Recent surveys of Middle East Studies research do not include any consideration of how scholars obtain access to their literary sources: e.g., Uriel Simonsohn, "Conversion to Islam: A Case Study for the Use of Legal Sources," History Compass 11 no. 8 (2013): 647-662; and Kevin W. Martin, "Middle East Historiography: Did We Miss the Cultural Turn?" History Compass 12 no. 2 (2014): 178-186. 
John Unsworth, "Documenting the Reinvention of Text: The Importance of Failure," Journal of Electronic Publishing 3 no. 2 (December 1997)

The good news is that the number of digitized manuscripts, typeset books and lithographs in Arabic script is steadily increasing. The bad news is that the digitization of Islamic books is such a decentralized process that it is very difficult to determine whether a digital surrogate of a particular text is already somewhere available on the Internet, possibly even as an OA resource. In Muslim societies in Eurasia and Africa the border between digital cultural heritage preservation and electronic publishing has been blurred, because digitization in the service of textual pragmatism reinforces indifference to the different historical and socio-economic contexts of textual production. At the moment the blog AMIR, ${ }^{101}$ which was initiated by Peter Magierski and is modeled on Charles Jones' blog AWOL, ${ }^{102}$ is the lone effort of tracking digitized OA resources in Middle Eastern and Islamic Studies. Scholars in other fields are usually surprised at this lack of coordination. ${ }^{103}$ But this professional failure reflects the transnational framework of Middle Eastern and Islamic Studies. Manuscripts in Arabic script are dispersed in private and public collections across the globe, and conversations about their digitization are conducted in emotionally charged contexts because of the political tensions between Europe and North America on the one hand and Muslim societies in Eurasia and Africa on the other. We would therefore rather not admit that our field's textual pragmatism has not furthered the bibliographic control over the manuscripts and printed books in Arabic script, even though at the current state of the cataloging of Islamic books, it is impossible to determine with a modicum of reliability for any text in how many copies it has been preserved. We cannot match literary works with manuscripts or printed books, as there are neither inventories of known texts written in the languages of Muslim societies nor inventories of known copies. Against this backdrop it is not surprising, though nonetheless regrettable, that painful decisions about the selection of Islamic books for digitization and their potential digital afterlife remain unacknowledged and are therefore not openly discussed. Instead, optimism about digitization prevails. We just need to get ahead of the technology, and those texts that are truly important, rare, or interesting will be eventually available as digital surrogates, even if not every book or document ever written can be digitized.

From my perspective the most urgent desideratum is an open and honest debate about digitization among those who have a stake in Middle Eastern and Islamic Studies. Since scholars inside and outside Muslim societies agree that written sources are crucial for our research, the question arises whether all of us bear at least some responsibility for their longterm preservation. If every society has indeed the government that it deserves, perhaps every academic field gets the sources, as well as the accompanying reference works and catalogs that it deserves. But what would our scholarly obligation to contribute to the preservation of rare manuscripts and printed books in Arabic script for future generations look like? A modest first step in the move from being happy-go-lucky consumers of digital surrogates whenever they happen to be available to being Digital Humanists would be the recognition that employing $\mathrm{DH}$ tools for Humanities and Social Sciences research is different from digitizing material artefacts in order to facilitate access to their literary content.

101 AMIR: Access to Mideast and Islamic Resources (ISSN 2160-3049), http://amirmideast.blogspot.com/.

102 AWOL: The Ancient World Online (ISSN 2156-2253), http://ancientworldonline.blogspot.com/. 103 See in particular the exasperated post by Klaus Graf, "Adventskalender (Türlein XI): Islamische Handschriften online," Archivalia (blog), 11 December 2010, http://archiv.twoday.net/stories/11445658/. 


\section{PS}

The first mention of a secondary source in the text is accompanied by a complete bibliographical reference in the footnote. In repeated mentions, the reference consists of the author's last name and an abbreviated title. The URLs of subscription-based resources are not indicated, and access dates are only provided for sources, such as press releases and newspaper articles. 